\section{Properties, application and degradation of plastics}

Agnieszka Szyszkowska, Dagmara Galas

DOI: $10.24131 / 3247.170107$

Summary:

The aim of the study was to present the role of polymeric materials in various industries. The article discusses the statistics related to the global production of plastics in the years 1950-2015. The paper presents the properties and application of polymer materials, and also made the characteristics of the processes of degradation of polymers, detailing the processes induced by chemical agents, physical and biological. Attention is paid to the characteristics of the biodegradation process. The work has also raised issues associated with the development of ever-larger amounts of polymer waste.

Key words: polymers, biodegradation, plastics

received: 11.07.2016; accepted: 30.12.2016; published: 18.04.2017

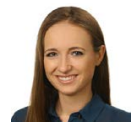

Agnieszka Szyszkowska: Faculty of Chemistry, Rzeszow University of Technology

a

\section{Overview}

This study is aimed to present the role of polymers in various economic sectors. The article describes statistics related to international production of plastics in the years 1950-2015. It provides properties and applications of polymer materials and characteristics of polymer degradation processes with details paid to processes generated by chemical, physical and biological factors. Special consideration was paid to the characteristics of the biodegradation process. The study also addresses issues related to the development of the increasing amounts of polymer waste.

\section{Introduction}

Polymer-based plastics are commonly available as materials used for making day-to-day items and specialized products such as prosthesis. They are often used to replace conventional materials such as wood, glass or paper. Every year, increasing amounts of polymer materials are manufactured. Polymer production in Poland amounts to approximately 2.1 million tons of polymers per annum (Endo et al., 2008) with global annual production reaching 300 million tons (Cordier et al., 2008). Synthetic polymers are widespread due to their ideal mechanical, chemical and physical properties. In addition, these properties greatly improve these materials' resistance to natural decomposition and microbial activity being the main cause of biodegradation and disposal of these materials (Saruchi et al. 2016).

\section{Aim of the study}

This study is aimed to review the literature concerning the issues related to polymer material biodegradation. It addresses statistical data related to the world- wide manufacture of plastics and presents properties and applications of polymer materials. It discusses the polymer degradation process with special attention paid to biodegradation.

\section{Review methods}

This study provides a review of Polish and English literature devoted to production and biodegradation processes involving polymer materials up to the year 2016. The literature was searched for in the PubMed as well as in Elsevier and Springer databases with the use of the following keywords: polymers, biodegradation, degradation, polymerization.

\section{Review results}

Worldwide production of plastics

Polymers are macromolecular organic compounds resulting from polymerization, i.e. bonding of single molecules (mers) into larger sections (polymers). They comprise the basic component for the production of

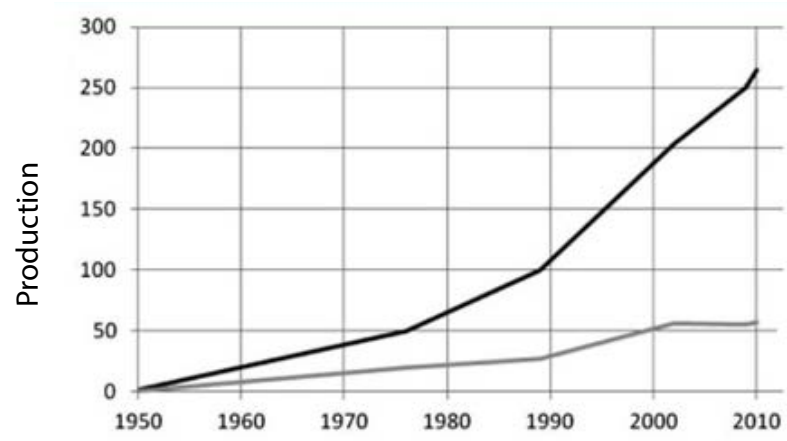

Fig. 1. Plastics production volume in Europe and around the world in the years 1950-2010

Source: Plastics Manufacturers in Europe Report, 2010. 
plastics (materials made of modified polymers, either natural or synthetic, and modifying additives, e.g. dyes).

In the recent years, a continuous growth in the production of plastics has been observed in Europe and around the world (Fig. 1). Between 1990-2000, the global production volume of plastics grew by approx. 100 million tons and further growth is being observed from year to year (Fig. 2). In 2010, 24\% of plastics were produced in China thus, making this country the world's leading manufacturer of plastic. Due to a growing level of significance of polymer materials, their production grows on a year-to-year basis (Plastics Manufacturers in Europe Report, 2010).

In 2014, there was a $5 \%$ growth (as compared to 2009) in the production of plastics in China making it still the largest global manufacturer of plastic materials. The percentage of Asian countries in global production of plastics in 2014 was $42 \%$ and 20\% for the European countries (Plastics Manufacturers in Europe Report, 2015).

Properties and applications of polymer materials

There is an increasing use of polymer materials due to their properties such as low weight, easy processing, durability, mechanical resistance, chemical resistance and low production costs. They have been applied in various industry sectors. In addition, they are also used as composite components to improve their physical and mechanical properties. This combination allows the user to obtain materials featuring low weight, biodegradability, high durability and stiffness, corrosion resistance and low friction coefficients. The polymer materials have been applied in numerous industry branches such as construction and electronic industry, medicine, transport, and home appliance manufacture.

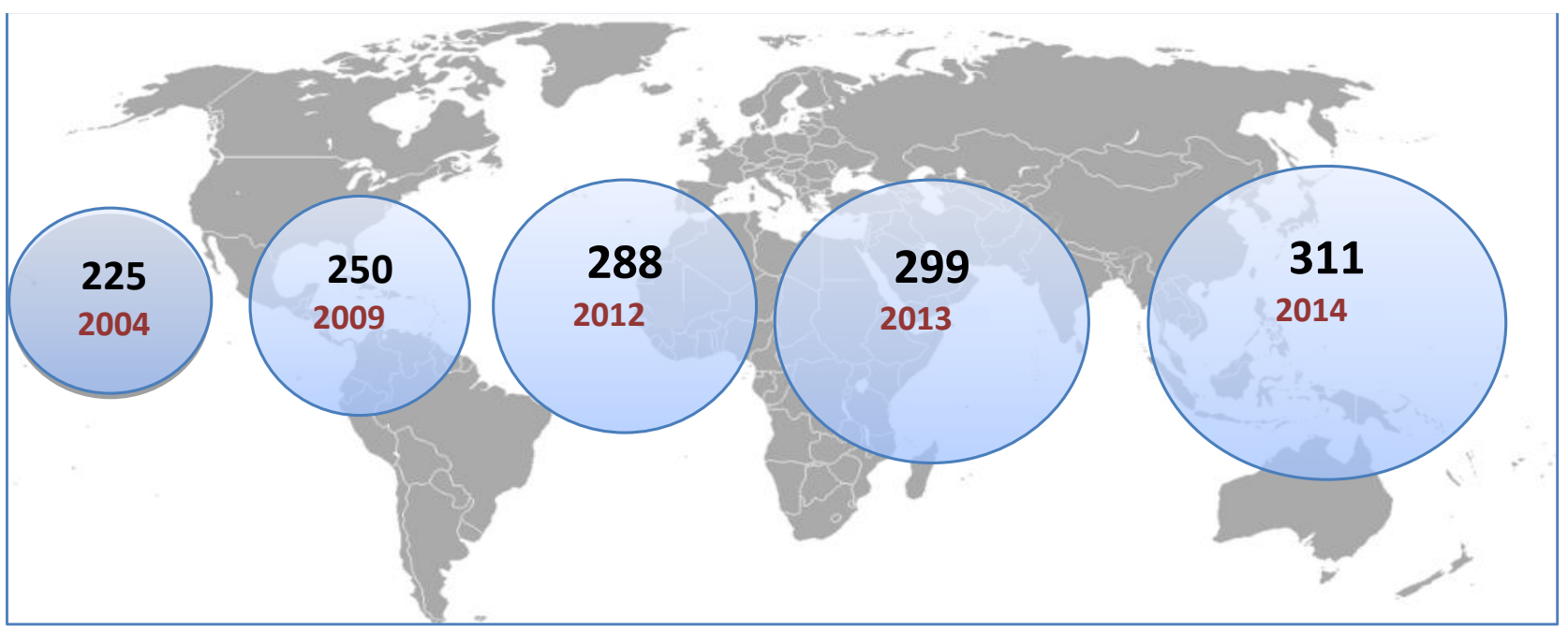

Fig. 2. Global plastics production growth over the years (in millions of tons per annum)

Source: own elaboration on the basis of Plastics Manufacturers in Europe Report, 2015.

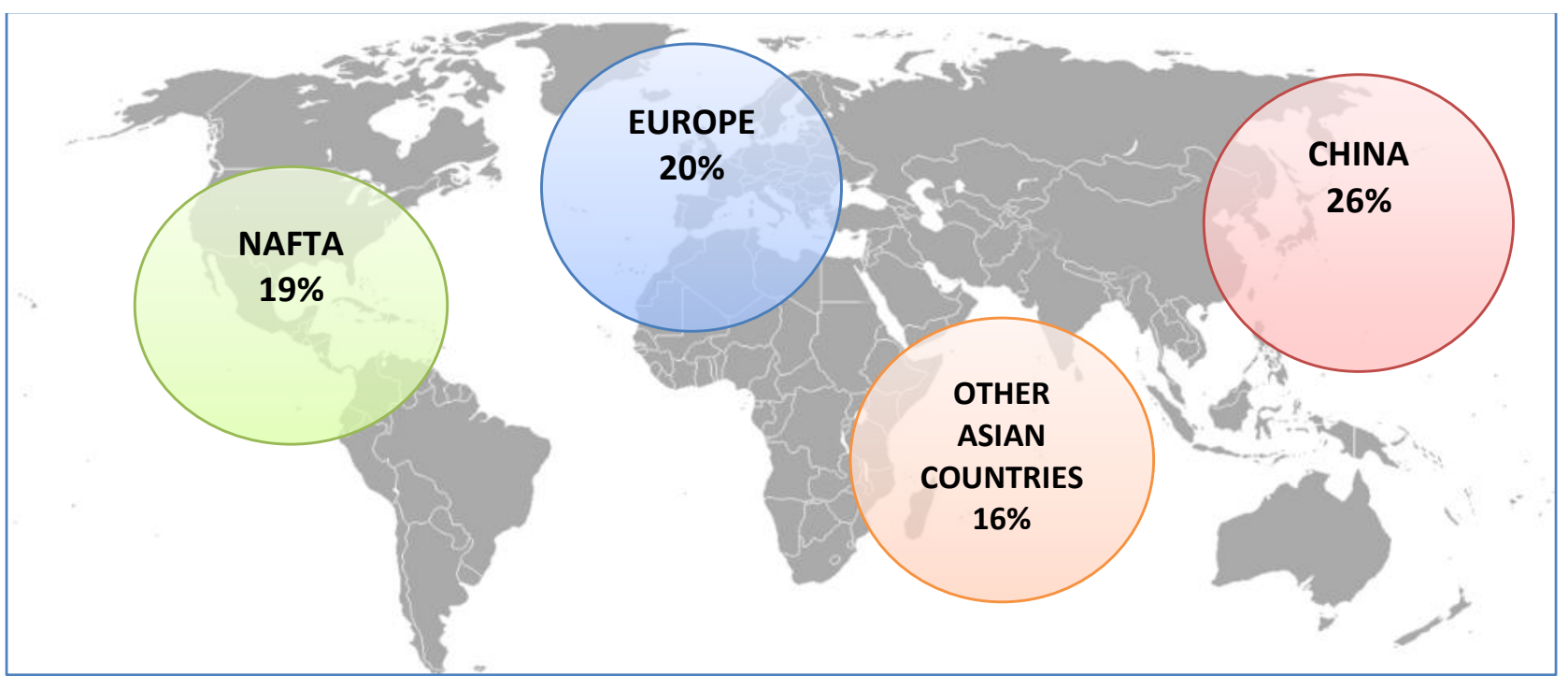

Fig. 3. Percentage of global production of plastics in 2014; NAFTA (North American Free Trade Agreement Source: own elaboration on the basis of Plastics Manufacturers of Europe Report, 2015 
Fig. 4. Plastic material

applications worldwide in 2015

Source: own elaboration on the basis of Plastics Manufacturers in Europe Report, 2015.

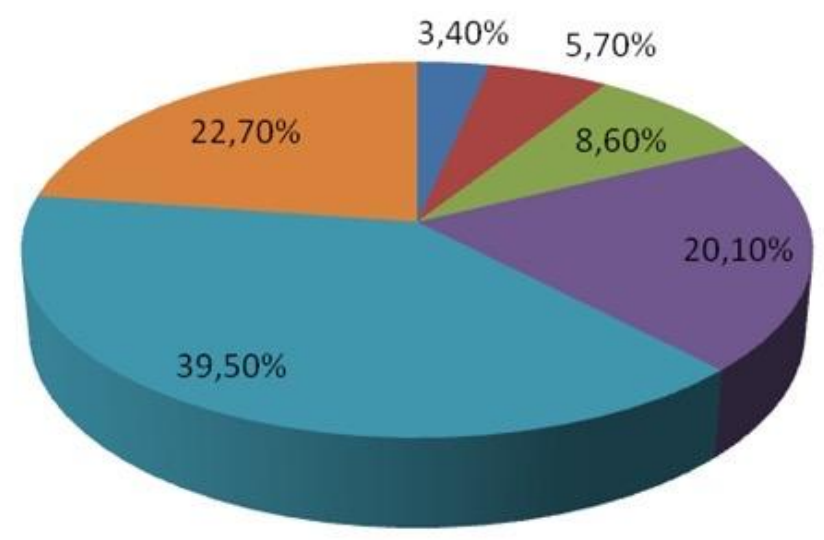

- Agriculture

- Electronics

automotive

- Construction

- Packaging

- Other
Just like in the previous years, in 2015, the largest amount of plastics was used to make various types of packaging (approx. 39.5\%). 22.7\% of plastics are used in the manufacture of home appliances, furniture, sport and medical articles. Furthermore, polymers are used in construction and automotive industries as well as electronics and agriculture (Plastics Manufacturers in Europe Report, 2015).

The most popular synthetic polymers include polyethylene (PE), poly(vinyl chloride) (PVC) or poly(ethylene terephthalate) (PET). The polyethylene created as a result of polymerization is commonly used to make plastic bags, bottles, packaging and foil (Shah et al., 2008). It also features extreme resistance to degradation. An estimated environmental decomposition time for polyethylene is approx. 300 years (Kyrikou et al., 2008) making it an enormously burdensome material for the environment. It generates disposal-related problems. The poly(vinyl chloride) is created as a result of vinyl chloride polymerization process. It is commonly used in the production of leads, cables, carpets, catheters and syringes. The poly(ethylene terephthalate) is a synthetic polyester applied in the manufacture of fast-drying fibers, photographic films, clothing, bot- tles and packaging of various types. The environmental degradation time for poly(ethylene terephthalate) ranges from 16 to 48 years (Shah et al., 2008).

\section{Degradation of polymers}

Depolymerization and degradation are polymer chain-destroying processes leading to polymer molecular mass limitations (Porejko and Zakrzewski, 1974; Rojek, 2011). The depolymerization causes polymers to be converted into monomers, thus making it a reaction opposite to polymerization. This process is used, inter alia, in plastic recycling processes as it allows the user to recover the monomers that can be reused for synthesis. An example of thermal depolymerization applied in recycling processes is decomposition of poly(methyl methacrylate) (the so-called Plexiglas). The monomer obtained as a result of this reaction comprises a substrate for re-polymerization (Żwir and Spychaj, 2007). Polymers can also decompose into low-molecular compounds other than monomers. For example, polyolefins exposed to UV and VIS radiation decompose while creating macroradicals and hydrogen. Then, under the influence of atmospheric oxygen, an oxidization process occurs that creates polar groups. Consequently, the polymer becomes brittle, it cracks while changing its color and losing its mechanical properties. The polymer decomposition processes may be caused by both physical factors (temperature, light) and chemical factors (acids, alkalis). Quite frequently, plastic exploitation processes involve polymer degradation processes that cause polymers to be disintegrated into fragments of large masses (but of smaller molecular masses as compared to those of the original polymer). The degradation may occur under the influence of physical factors (ionizing radiations, ultrasounds, sunlight, high temperatures), biological factors (enzymes, bacteria, fungus) and chemical factors (air, etc.). The following are found to be the most important effects of polymer degradation process:

- Separation of atoms and functional groups from polymer chain leading to changes in chemical structure of a single structural unit;

- Random ruptures within main carbon chain;

- Creation of bonds between structural units belonging to various polymer chains (cross-linking process);

- Introduction of lateral substituents into the main polymer chain (Florjańczyk and Penczek, 2002; Stevens 1983; Czaja 2005).

\section{Types of polymer degradation}

The type of the factor causing multi-molecular compounds to decompose provides the most frequent basis for the classification of polymer degradation processes (Kaczmarek and Rabek, 1997; Mucha 2002; Zinowicz et al., 2003,). The following types of polymer degradation are distinguished:

Degradations occurring under the influence of physical factors:

- Mechanical degradation refers to macroscopic effects that occur in polymers due to fragmenta- 
tion, grinding, freezing, melting, etc. The shearing forces generate tensions capable of overcoming the energy of valence bonds between polymer chain carbon atoms. This results in structural changes of the material that are either local or can include the entire surface (Booth, 1963).

- Thermal degradation occurs when a polymer changes its properties under the influence of higher temperature. These changes may be of reversible and irreversible nature. The reversible changes include phase transformations, supermolecularstructure disaggregation and transformation of polymer into viscous liquid state. As regards the irreversible changes, they refer to above flow-temperature processes which are often accompanied by the process of freeing low-molecular volatile compounds such as carbon dioxide, alkanes, alkenes, amines and water (Villetti et al., 2002; Madorsky and Straus, 1959). Quite frequently, plastics contain additional components (e.g. dyes, fillers, stabilizers) that may react with polymers in higher temperatures thus, causing thermal and chemical degradation.

- Photochemical degradation occurs under the influence of light. The light-absorbing chromophoric groups in the polymer chain must be present for this reaction to occur. The products made of such polymers are at risk of being exposed to sunlight or may get damaged as a result of this type of degradation (Kumari et al., 2001).

- Degradation by radiation occurs under the influence of X-rays and gamma radiation. It leads to structural changes in polymers, mainly to crosslinking, generating volatile products and cyclization. Degradation triggered by high-power radiation occurs more rapidly as compared to degradations imposed by other factors (Żenkiewicz, 2005).
Degradations occurring under the influence of chemical factors:

- Atmospheric degradation occurs in line with photo oxidation and thermal oxidation. The photo oxidation is the result of UV radiation in the presence of oxygen and occurs mainly on polymer surface. The thermal oxidation takes place in increased temperatures. The process may occur in the entire volume of the material. The atmospheric degradation leads to changes in chemical composition of polymers and molecular masses and it also can lead to cracks and gouges on the surface (Guarrotxena and Millan, 1999).

- Chemical degradation is initiated by chemical compounds of low molecular masses and leads to destruction of polymer materials.

Degradations occurring under the influence of biological factors:

- Biological degradation refers to environmental decomposition of polymer materials following a specific period of time due to the activity of enzymes discharged by microorganisms under the conditions that are favorable for their growth. This consequently leads to shorter polymer chains, changes in physical and chemical properties as well as mechanical properties of polymers (Grabowska, 2010).

Generally, a polymer degradation triggered by physical factors is often referred to as a polymer ageing process whereas in case of chemical factor-triggered degradations, it is called a polymer corrosion (Rabek, 1977).

\section{Biodegradation}

Biodegradation (gr. bios - life, lat. degradatio - reduction) is a specific property of some of polymer materials and it refers to decomposition of materials under the influence of biotic factors. Microorganisms treat polymers as potential sources of organic compounds (sugars, amino acids, etc.) that can be transformed into life-sustainable energy. Biodegradation is not a process limited merely to the world of microorganisms. Microorganisms are always present in a material biodegradation process while part of the whole mechanism may be of an abiotic character (Shah et al., 2013; Scharnweber, 2016). On the most frequent basis, polymers degrade in a two-step way by going through initial and final degradation phases (Fig. 5). The first phase includes macroscopic changes such as discolorations, increased brittleness and decreased physical properties of polymer materials. These modifications occur due to the impact of sunlight, oxygen, water, temperature, tensions and microorganisms. The primary carbon-carbon bonds in the polymer chain are ruptured thus, creating shorter chains. This leads to a decreased molecular mass which is the result of hydrolysis in the water environment with or without the participation of enzymes under the abiotic conditions. The reduced number of branches and molecular mass of the compound causes it to become more available for microorganisms carrying out a proper biodegradation process. In the second phase, the created polymer fragments are mineralized into carbon dioxide, water and biomass (oxidative conditions) or methane, carbon dioxide and biomass (non-oxidative conditions). Standard organic compounds degraded by microorganisms must first reach the inside of the cell either through passive diffusion or specific transport systems. However, in case of large-size polymer substrates, the biodegradation process is initiated by extracellular enzymes which trigger an initial decomposition of the compound (Lucas et al., 2008; Eubeler et al., 2009; Krzan et al., 2006; Briassoulis, 2006).

A lot of factors, such as polymer type (molecular mass, crystal and amorphous phase, specific surface development degree, porosity level), microorganism type, 
discharged enzyme type and variable conditions during current reactions ( $\mathrm{pH}$, temperature, humidity), impact the biodegradation process. This process is facilitated by soils abounding in humus that comprise an environment suitable for the development of microorganisms (Kołwzan et al., 2005). It is assumed that during biodegradation two types of reaction occur - hydrolysis and oxidization. These reactions may occur either in a simultaneous or consecutive way. Biodegradation processes tend to be time consuming and changes to mechanical properties, loss of mass and a decrease in degradation levels occur gradually (Leja and Lewandowicz, 2010; Webb et al., 2013).

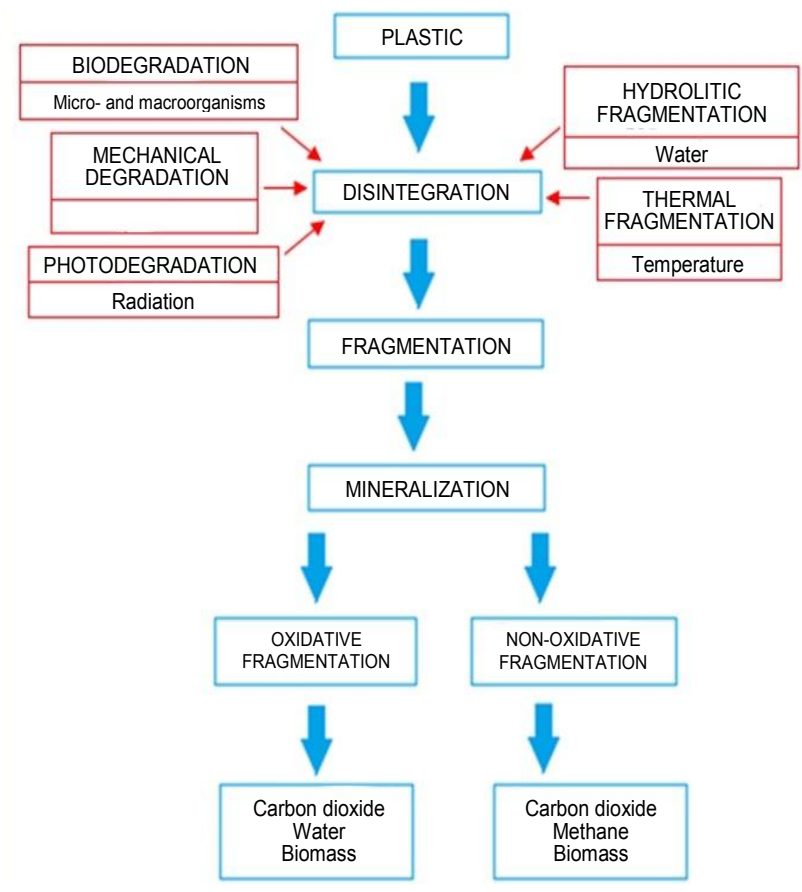

Aside from plastics utilization, the biodegradation process is also applied in sewage treatment plants as part of fermentation-based purification processes carried out in biological ponds. Biodegradation is also used for bioremediation (removal of impurities from subsoil waters and soils with the help of microorganisms) or purification of soils contaminated with petroleum products (Kumar et al., 2011).

\section{Oxo-biodegradation}

Oxo-biodegradation of plastics consists in decomposing plastic into smaller fragments which are then subjected to further biodegradation. The process is accelerated by external factors such as a prodegradant (catalyst) (Rodrigues da Luz et al., 2014). The prodegradants are usually salts (stearates, dithiocarbamates) of transition metals capable of changing the oxidization level (Fe, Co, Mn, and others) (Paukszta, 2015). Another stage is the mineralization process with the participation of microorganisms. The physical factors that activate the decomposition process include solar radiation (UV), temperature, pressure and mechanical damages. The oxo-biodegradable materials degrade in both open and closed systems and do not require the presence of water. Their decomposition time is shorter than for standard plastics and may also be adjusted to user's needs by the manufacturer. The oxo-biodegradable plastics may also be manufactured from recovered raw materials (Gibas and Rymarz, 2009; Portillo et al., 2016). The oxo-biodegradation of plastics in natural environment occurs under the influence of oxygen and is accelerated by solar radiation. Fragments of plastic are absorbed by the microorganisms which transform it into carbon dioxide, water and biomass.

\section{Biodegradation vs environment}

An ability to succumb to biodegradation processes is currently a desirable property of plastic products. It eliminates the long-term waste storage requirement. The advantage of biodegradable products is that they decompose quickly into very small fragments. However, nano- and picoplastic resulting from this process may be swallowed by live organisms or penetrate through cell membranes and directly damage the inner organs of the organisms. On the other hand, traditional plastics are not biodegradable and remain in the environment as a growing ecological threat (dangerous plastic components may penetrate all trophic levels). Another advantage of biodegradable plastic packaging is the option to collect such products together with organic waste and then to utilize them by composting in industrial installations to prevent costly recovery. Organic waste composting processes are based on natural biochemical processes and are relatively safe in environmental terms (Stachurek, 2012; Gross and Kalra, 2002; Kucharczak et al., 2010).

\section{Conclusions}

Growing market demand for polymer plastics stimulates increased production of these products and along with it comes the creation of enormous amounts of waste (25.8 million tons in 2014 in EU states). Plastics feature a very extensive decomposition time causing great difficulties related to their utilization. However, these materials are pretty comfortable to use and for this reason new plastic degradation methods are still being searched for. Expanding our knowledge in this area is still of great significance as degradation methods applied nowadays are still far from being perfect.

Fig. 5. Polymer degradation process. 


\section{References}

Artham T, Doble M (2008). Biodegradation of aliphatic and aromatic polycarbonates. Macromol. Biosci. 8: 14-24.

Booth C (1963). The mechanical degradation of polymers. Polymer. 4:471-478.

Briassoulis D (2006). Mechanical behaviour of biodegradable agricultural films under real field coditions. Polym. Degrad. Stabil. 91: 1256-1272.

Cordier P, Tournilhac F, Soulie-Ziakowic C, Leibler L (2008). Self - healing and thermoreversible rubber from supramolecular assembly, Nature 451:977-980.

Endo K, Kubo N, Ishida T (2008). Polymerization of Cyclic-Disulphides and Formation of Gel Structure Containing Polycatenane, KGK-Kaut Gummi Kunst. 61:176-179.

Eubeler J, Bernhard S, Knepper T (2009). Environmental biodegradation of synthetic polymers I. Test methodologies and procedures. Trends Anal. Chem. 28: 1057-1072.

Florjańczyk Z, Penczek S (2002). Chemia polimerów tom I. Wydawnictwo Politechniki Warszawskiej.

Gibas E, Rymarz G (2009). Termoplastyczne polimery oksy-biodegradowalne. Przetwórstwo Tworzyw 2: 24-33.

Grabowska B (2010). Biodegradacja tworzyw polimerowych. Archives of Foundry Engineering 10:57-60.

Gross RA, Kalra B (2002). Biodegradable Polymers for the Environment. Science. 297: 803-807.

Guarrotxena N, Millan J (1999). Radiation-iduced ageing.II Kinetics of the evolution of mechanical properties. Revista de Plasticos Modernos. 78: 143-151.

Kaczmarek H, Rabek JF (1997). Angew. Mikromol. Chem. 247: 111-

Kołwzan B, Adamiak W, Grabas K, Pawełczyk A (2005). Podstawy mikrobiologii w ochronie środowiska. Oficyna Wydawnicza Politechniki Wrocławskiej.

Krzan A, Hemjinda S, Miertus S, Corti A, Chiellini E (2006). Standardization and certification in the area of environmentally degradable plastics. Polym. Degrad. Stabil. 91: 2819-2833.

Kucharczak K, Stępień W, Gworek B (2010). Kompostowanie odpadów komunalnych jako metoda odzysku substancji organicznej. Ochr. Środ. i Zasob. Natur. 42: 240-254.

Kumar AA, Karthick K., Arumugam KP (2011). Biodegradable Polymers an Its Applications. Int. J. Biosci. Biochem. Bioinforma. 1: 173-176.

Kumari A, Roy RS, Jha HK (2001). Study of photoradical ageing of polymers. Acta Ciencia Indica, Pfysics. 23: 195-200.

Kyrikou I, Briassoulis D (2007). Biodegradation of agricultural plastic films: a critical review. J. Polym. Environ. 15:125-150.

Leja K, Lewandowicz G (2010). Polymers Biodegradation and Bio- degradable Polymers - a Review. Polish J. of Environ. Stud. 19: $255-266$

Lucas N, Bienaime C, Belloy C, Queneudec M, Silvestre F, NavaSaucedo J (2008). Polymers biodegradation: Mechanisms and estimation techniques - A review. Chemosphere. 73: 429-442.

Madorsky SL, Straus S (1959). Thermal Degradation of Polymers at High Temperature. Journal of Research of the National Bureau of Standards- A Physics and Chemistry. 63 A: 307-311.

Mucha M (2002). Polimery a ekologia. Wydawnictwo Politechniki Łódzkiej.

Omrani E, Menezes PL, Rohatgi PK (2016). State of the art on tribological behavior of polymer matrix composites reinforced with natural fibres in the green materials world. ESTIJ. 19:717-736.

Portillo F, Yashchuck O, Hermida E (2016). Evaluation of the rate abiotic and biotic degradation of oxo-degradable polyethylene. Polym. Test. 53: 58-69.

Porejko S, Zakrzewski L (1974). Chemia związków wielkocząsteczkowych. WNT.

Rabek JF (1977). Podstawy fizykochemii polimerów. Wydawnictwo Politechniki Wrocławskiej.

Raport Europejskich Producentów tworzyw sztucznych i ich partnerów PlasticsEurope (2010). Tworzywa sztuczne - fakty 2011. Analiza produkcji, zapotrzebowania oraz odzysku tworzyw sztucznych w Europie w roku 2010.

Raport Europejskich Producentów tworzyw sztucznych i ich partnerów PlasticsEurope (2015). Tworzywa sztuczne - fakty 2015. Analiza produkcji, zapotrzebowania oraz odzysku tworzyw sztucznych w Europie w roku 2015

Rodrigues da Luz JM, Paes SA, Bazzolli DMS, Totola MR, Demuner AJ, Kasuya MCM (2014). Abiotic and Biotic Degradation of Oxo-Biodegradable Plastic Bags by Pleurotus ostreatus. PLoS 9 (11). Dostępny na http://journals.plos.org/plosone/ article?id=10.1371\%2Fjournal.pone.0107438\#authcontrib. Dostęp 07.07.2016

Rojek M (2011). Metodologia badań diagnostycznych warstwowych materiałów kompozytowych o osnowie polimerowej. Dostępny na http://delibra.bg.polsl.pl/Content/26766/BCPS_30417_2011_ Metodologia-badandi_0000.pdf. Dostęp 07.07.2016.

Saruchi, Kaith BS, Kumar V, Jindal R (2016). Biodegradation study of enzymatically catalyzed interpenetrating polymer network: Evaluation of agrochemical release and impact on soil fertility. Biotechnol Rep. 9: 74-81.

Shah AA, Hasan F, Hameed A, Ahmed S (2008). Biologically degradation of plastics: a comprehensive review. Biotechnol. Adv. 26 246-265.

Shah AA, Hasan F, Shah Z, Kanwal N, Zeb A (2013). Biodegradation of natural and synthetic rubbers: A review. Int. Biodeter. Biodegr. 83: 145-157.
Stachurek I (2012). Problemy z biodegradacją tworzyw sztucznych w środowisku. Zeszyty Naukowe Wyższej Szkoły Zarządzania Ochroną Pracy w Katowicach 1:74-108.

Stevens MP (1983). Wprowadzenie do chemii polimerów. PWN.

Webb HK, Arnott J, Crawford RJ, Ivanova EP (2013). Plastic Degradation and Its Environmental Implications with Special Reference to Poly(ethylene terephthalate). Polymers 5: 1-18.

Villetti MA, Crespo JS, Soldi MS, Pires ATN, Borsali R, Soldi V (2002). Thermal degradation of natural polymers. J. Therm. Anal. Calorim. 67: 295-303.

Zinowicz Z, Gołębiewski J, Świć A (2003). Technologiczne problemy zagospodarowania odpadów tworzyw polimerowych. Wydawnictwo Politechniki Lubelskiej.

Żenkiewicz M (2005). Wybrane zagadnienia modyfikowania materiałów polimerowych za pomocą promieniowania elektronowego o dużej energii. Polimery. 50:4-9.

Żwir MJ, Spychaj T (2007). Recykling surowcowy odpadów Poli(met akrylanu metylu). Chemik 60: 390-399. 